\title{
High-temperature Tensile Behavior in Coarse-grained and Fine-grained Nb-containing 25Cr-20Ni Austenitic Stainless Steel
}

\author{
Guodong $\mathrm{Hu}^{1,2,3,4} \cdot$ Pei Wang ${ }^{1}$. Dianzhong $\mathrm{Li}^{1} \cdot \mathrm{Yiyi}_{\mathrm{Li}}{ }^{1}$
}

Received: 2 January 2020 / Revised: 24 February 2020 / Published online: 23 June 2020

(c) The Chinese Society for Metals (CSM) and Springer-Verlag GmbH Germany, part of Springer Nature 2020

\begin{abstract}
In this study, tensile behavior of $\mathrm{Nb}$-containing $25 \mathrm{Cr}-20 \mathrm{Ni}$ austenitic stainless steels composed of coarse or fine grains has been investigated at temperatures ranging from room temperature to $900{ }^{\circ} \mathrm{C}$. Results show that the tensile strength of fine-grained specimens decreases faster than that of coarse-grained specimens, as the test temperature increases from 600 ${ }^{\circ} \mathrm{C}$ to $800{ }^{\circ} \mathrm{C}$. The rapidly decreasing tensile strength is attributed to the enhanced dynamic recovery and recrystallization, because additional slip systems are activated, and cross-slipping is accelerated during deformation in fine-grained specimens. After tensile testing at $700-900{ }^{\circ} \mathrm{C}$, sigma phases are formed concurrently with dynamic recrystallization in fine-grained specimens. The precipitation of sigma phases is induced by simultaneous recrystallization as the diffusion of alloying elements is accelerated during the recrystallization process. Additionally, the minimum ductility is observed in coarse-grained specimens at $800{ }^{\circ} \mathrm{C}$, which is caused by the formation of $M_{23} \mathrm{C}_{6}$ precipitates at the grain boundaries.
\end{abstract}

Keywords Austenitic stainless steels $\cdot$ High-temperature tensile properties $\cdot$ Grain size $\cdot$ Precipitates

\section{Introduction}

$25 \mathrm{Cr}-20 \mathrm{Ni}$ austenitic stainless steels are widely used in advanced nuclear industries and fossil fuel power plants for their excellent high-temperature corrosion resistance and creep properties [1,2]. Grain size is one of the essential factors determining the mechanical properties and corrosion resistance of austenitic stainless steels [3]. For instance, it is recommended that $\mathrm{HR} 3 \mathrm{C}$ steel has coarse grains to obtain superior creep properties, whereas another widely used

Available online at https://link.springer.com/journal/40195.

Pei Wang

pwang@imr.ac.cn

1 Shenyang National Laboratory for Materials Science, Institute of Metal Research, Chinese Academy of Sciences, 72 Wenhua Road, Shenyang 110016, China

2 School of Materials Science and Engineering, University of Science and Technology of China, 72 Wenhua Road, Shenyang 110016, China

3 Centre of Excellence for Advanced Materials, Dongguan 523808, China

4 Songshan Lake Laboratory for Materials Science, Dongguan 523808, China austenitic heat resistant steel, Super304H, has fine grains for good oxidation resistance. It is difficult to clarify the relationship between grain size and mechanical properties in austenitic heat resistant materials, especially in $\mathrm{Nb}$ - and Ti-containing austenitic stainless steels. This is because the change of grain size is always accompanied by variations in the volume fraction and types of precipitates in the matrix. For instance, the higher solution temperature required to obtain a larger grain size generally causes a change in precipitate content and the microstructure of the matrix simultaneously $[4,5]$. Additionally, grain size influences the nucleation sites and element diffusion for precipitation [6].

The effects of grain size on the strength of austenitic steels have been investigated extensively [7-9]. There is a general agreement that grain refinement improves yield strength at low strain, according to the Hall-Petch law, when the temperature is below $0.62 T_{\mathrm{m}}[10,11]$. Nevertheless, an inverse Hall-Petch relationship is observed at temperatures higher than $0.74 T_{\mathrm{m}}$. At a larger strain after yielding, the strength is a result of the plastic strain history and the strain gradient in grains [12]. The flow stress of materials at higher strain is influenced by intergranular stress (corresponding to the deformation in grain boundary regions) and intragranular stress (corresponding to the deformation in grain interior regions) [13]. The ratio of intergranular 
to intragranular stress is influenced by the grain size [14]. Generally, the contribution of intergranular stress to the total flow stress increases with decreasing grain size. As proposed by Miyazaki, the elastic strain in the deformationaffected zone, which comprises neighboring grains around the deformed grain, increases with decreasing grain size [15]. During plastic deformation of fine-grained materials, more slip systems are activated due to the larger constraining stress by neighboring grains, thus leading to easier plastic deformation and a smaller flow stress increment [12].

Grain size also influences the ductility of austenitic stainless steels. The ductility of coarse-grained materials is better than that of fine-grained materials at low temperatures, as dislocations are more likely to accumulate at grain boundaries (GBs) rather than interacting in the grain interior as in fine-grained microstructures [16]. The dislocation density is easily saturated at the GBs after a small plastic deformation, thus resulting in lower ductility in fine-grained materials [17]. At high temperatures, a minimum ductility is always observed during high-temperature tensile tests, and the temperature corresponding to the minimum ductility increases with increasing grain size [10, 18]. The type of fracture at the minimum ductility is intragranular fracture for fine-grained materials but mainly intergranular fracture for coarse-grained materials. There are a range of interpretations on the reported measurements of the ductility minimum. For example, Mannan et al. reported that the ductility minimum in fine-grained materials is caused by the maximum rate of GB sliding during deformation [10]. In the research of Rao et al., the presence of $\mathrm{Cr}_{2} \mathrm{~N}$ precipitates is found to induce a minimum ductility in fine-grained microstructures [11]. On the other hand, the precipitation of $M_{23} \mathrm{C}_{6}$ at the GBs, inducing intergranular fracture, is proposed as a cause for the ductility minimum in coarse-grained materials [19]. This is because the temperature range of intergranular fracture corresponds well with the $M_{23} \mathrm{C}_{6}$ precipitation temperature [20, 21], and the $M_{23} \mathrm{C}_{6}$ carbides at the GB decrease the ductility in austenitic stainless steels due to their low cohesion with the matrix [22-24].

In the past, many studies have reported on the effects of grain size on the mechanical properties of austenitic stainless steels at different temperatures [9, 11, 25]. However, most of them focused on the influence of GBs and variation of grain size on the mechanical properties in $\mathrm{Nb}$ - and Ti-free TP304 or TP316 steels. The possible implications of concurrent precipitation and deformation microstructure evolution in $\mathrm{Nb}$ - and Ti-containing austenitic stainless steels were neglected. Therefore, this work is carried out with the aim of investigating the effects of grain size on deformation mechanisms, precipitate evolution, and the consequent mechanical properties during high-temperature tensile tests. In this study, the microstructure and mechanical behavior of both fine- and coarse-grained $\mathrm{Nb}$-containing $25 \mathrm{Cr}-20 \mathrm{Ni}$ austenitic stainless steels were systematically investigated at different temperatures.

\section{Experimental}

The $25 \mathrm{~kg}$ ingot of investigated steel was prepared by vacuum induction melting in laboratory. The chemical compositions are listed in Table 1. The ingot was hot-forged to $45 \mathrm{~mm} \times 45 \mathrm{~mm}$ rod at $1150{ }^{\circ} \mathrm{C}$ to $950{ }^{\circ} \mathrm{C}$. After forging, the rod was pre-solution-heated at $1300^{\circ} \mathrm{C}$ for $2 \mathrm{~h}$ to eliminate micro-segregation and dissolve primary $\mathrm{NbC}$ particles formed during solidification. Hot continuous rolling was subsequently carried out at $1100{ }^{\circ} \mathrm{C}$ to acquire a round bar with diameter of $18 \mathrm{~mm}$. The hot rolled bars were then treated with solid solution treatment for $20 \mathrm{~min}$ at 1020 ${ }^{\circ} \mathrm{C}$ to obtain fine-grained material and $1200{ }^{\circ} \mathrm{C}$ to obtain coarse-grained material, respectively, and followed by water quenched to room temperature. Cylindrical tensile specimens with diameter of $5 \mathrm{~mm}$ and gauge length of $25 \mathrm{~mm}$ were prepared. Tensile tests were performed on an MTS E45 105 machine between room temperature (RT) and $900{ }^{\circ} \mathrm{C}$ in air. Thermal insulation for $10 \mathrm{~min}$ was carried out before the high-temperature tensile test. According to the standard GB/T 228-2015 (China), the tensile tests at RT were performed at a constant strain rate of $3 \times 10^{-4} \mathrm{~s}^{-1}$ when the strain was smaller than $6 \%$ and $2 \times 10^{-3} \mathrm{~s}^{-1}$ when the strain was larger than $6 \%$. For the high-temperature tensile tests at $400-900{ }^{\circ} \mathrm{C}$, the constant strain rate was $1 \times 10^{-4} \mathrm{~s}^{-1}$ when the strain was smaller than $6 \%$ and $1.3 \times 10^{-3} \mathrm{~s}^{-1}$ when the strain was larger than $6 \%$. The increasing strain rate at $6 \%$ strain was for shortening test time according to the standard GB/T 228-2015. After tensile failure, the elongation and $Z$ reduction of the tensile sample were measured.

The microstructure of failed specimens on longitudinal section was observed under ZEISS Axio Lab. A1 optical microscopy (OM). ZEISS SUPRA 35 scanning electron microscopy (SEM) with energy-dispersive spectroscopy (EDS) was used for precipitate characterization. The longitudinal section microstructure under OM and SEM was observed at the region $\sim 5 \mathrm{~mm}$ from the fractural surface. The specimens for grain size characterization were electrolytic etched by $60 \%$ nitric acid and $40 \%$ water, while specimens
Table 1 Chemical compositions of the experimental steel (wt.\%)

\begin{tabular}{llllllll}
\hline $\mathrm{C}$ & $\mathrm{Si}$ & $\mathrm{Mn}$ & $\mathrm{Cr}$ & $\mathrm{Ni}$ & $\mathrm{Nb}$ & $\mathrm{N}$ & $\mathrm{Fe}$ \\
\hline 0.060 & 0.83 & 1.64 & 23.95 & 19.54 & 0.32 & 0.078 & Bal. \\
\hline
\end{tabular}


for precipitate observation were electrolytic etch by $40 \%$ nitrohydrochloric acid and $60 \%$ water. The dislocation and precipitates were further observed using FEI Tecnai F20 transmission electron microscopy (TEM). All of the TEM specimens were obtained at the region $\sim 5 \mathrm{~mm}$ from the fractural zone, perpendicular to the tensile axis. The TEM foil specimens were mechanically polished to a thickness of $\sim 50$ $\mu \mathrm{m}$, and then electro-polished by a standard twin jet procedure using an etching solution of $90 \%$ acetic acid and $10 \%$ perchloric acid at $-25^{\circ} \mathrm{C}$ with an operating voltage of $20 \mathrm{~V}$.

\section{Results}

\subsection{Initial Microstructure of FG-specimen and CG-specimen}

Figure 1 shows the microstructure of the materials under investigation after a solution treatment at $1020{ }^{\circ} \mathrm{C}$ and 1200 ${ }^{\circ} \mathrm{C}$. The average grain size is about $8 \mu \mathrm{m}$ in the fine-grained specimen (FG-specimen) and about $70 \mu \mathrm{m}$ in the coarsegrained specimen (CG-specimen), respectively, as shown in Fig. 1a, d. The FG-specimen contains large amounts of fine precipitates in the matrix (Fig. 1b), while few precipitates are observed in the CG-specimen (Fig. 1e). TEM micrographs indicate that the precipitates in the FG-specimen are around $100 \mathrm{~nm}$ in size (Fig. 1c), rich in $\mathrm{Nb}$ according to the energy-dispersive spectroscopy (EDS) mapping results (inset picture in Fig. 1c). A small quantity of precipitates with a size of around $20 \mathrm{~nm}$ are observed in the CG-specimen under TEM observation (Fig. 1f).

\subsection{Tensile Properties of FG-specimens and CG-specimens at Different Temperatures}

The engineering stress-strain curves are illustrated in Fig. 2. The strength of both specimen types decreases with increasing test temperature. Serration is found in the stress-strain curves at $500{ }^{\circ} \mathrm{C}$ and $600{ }^{\circ} \mathrm{C}$, indicating that dynamic strain aging (DSA) occurs in both the FG- and CG-specimens. However, the serration in the curves of the CG-specimens is not as great as in the FG-specimens. Research has shown that fine-grained material enhances DSA serration as DSA occurs preferentially at GBs. This is because GBs act as local obstacles to dislocation motion [26]. Figure 3a shows the ultimate tensile strength (UTS) and yield strength (YS) of the specimen types between room temperature (RT) and $900{ }^{\circ} \mathrm{C}$. Between RT and $800{ }^{\circ} \mathrm{C}$, the YS of both FG- and

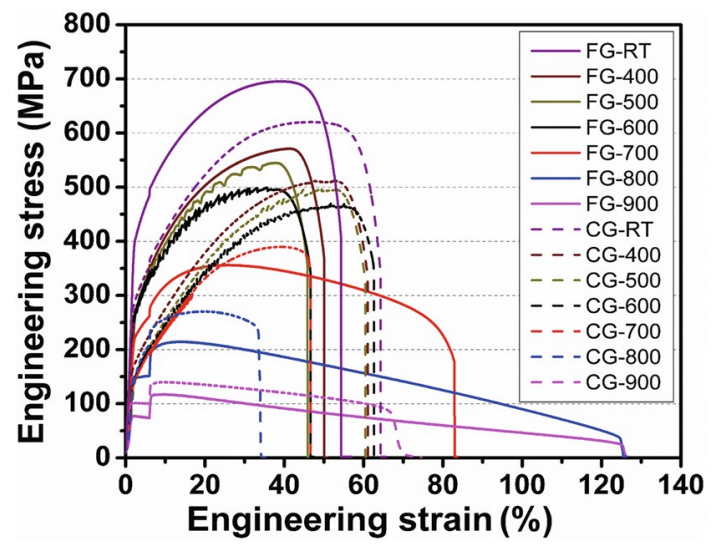

Fig. 2 Temperature dependence of the engineering stress-strain curves for the tested specimens
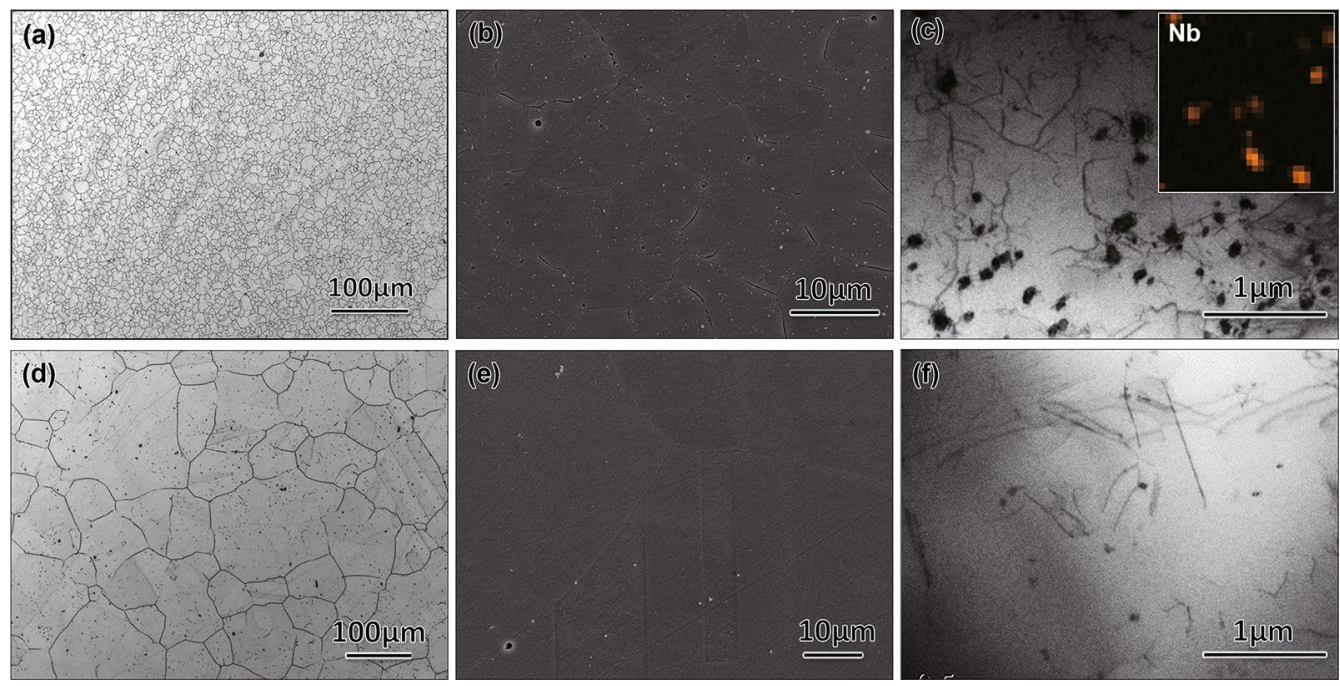

Fig. 1 Initial microstructure of fine-grained specimen in a OM, b SEM, c TEM micrograph; coarse-grained specimen in $\mathbf{d}$ OM, e SEM, f TEM micrograph. The inset in $\mathbf{c}$ shows the EDS mapping of Nb-rich precipitates 

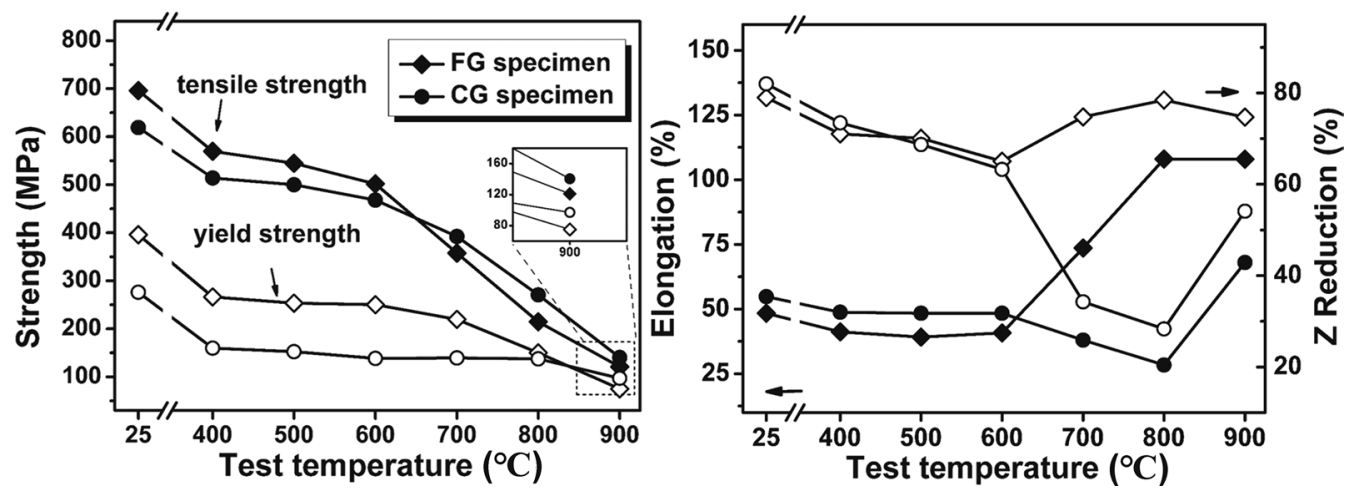

Fig. 3 a UTS and YS, b elongation and $Z$ reduction of the investigated specimens at different test temperatures

CG-specimens is weakly temperature dependent compared with the UTS, and the YS of the FG-specimens is higher than that of the CG-specimens. However, as the test temperature increases to $900{ }^{\circ} \mathrm{C}$, the YS of the FG-specimens decreases markedly and becomes lower than that of the CGspecimens. By contrast, the UTS of both specimen types decreases constantly with increasing test temperature. Specifically, the UTS of the FG-specimens is higher than that of the CG-specimens between RT and $600{ }^{\circ} \mathrm{C}$. As the test temperature increases above $700^{\circ} \mathrm{C}$, however, the UTS of the FG-specimens decreases rapidly and is lower than that of the CG-specimens. Figure $3 \mathrm{~b}$ shows the elongation and $Z$ reduction of the specimens from RT to $900{ }^{\circ} \mathrm{C}$. From RT to $600{ }^{\circ} \mathrm{C}$, the elongation of both specimen types is similar and changes little with temperature. As the test temperature increases from $600{ }^{\circ} \mathrm{C}$ to $900{ }^{\circ} \mathrm{C}$, the elongation of the two specimen types changes in different ways. Between $600{ }^{\circ} \mathrm{C}$ and $800{ }^{\circ} \mathrm{C}$, the elongation of the FG-specimens increases markedly and remains constant between $800{ }^{\circ} \mathrm{C}$ and $900{ }^{\circ} \mathrm{C}$. For the CG-specimens, the elongation decreases from 600 ${ }^{\circ} \mathrm{C}$ to $800{ }^{\circ} \mathrm{C}$, where reaches a minimum, and then increases between $800{ }^{\circ} \mathrm{C}$ and $900{ }^{\circ} \mathrm{C}$. The variation of $Z$ reduction with test temperature of both specimen types is similar to their change of elongation with temperature, as shown in Fig. 3b.

\subsection{Microstructure Evolution During Deformation}

The deformed microstructures were analyzed to clarify the deformation mechanisms of the materials with different grain sizes. The OM micrographs in Fig. 4a-c show the microstructure of the FG-specimens in longitudinal section after tensile tests at RT, $400{ }^{\circ} \mathrm{C}$ and $600{ }^{\circ} \mathrm{C}$. The deformed grains are elongated along the tensile axis. The microstructures of the FG-specimens after tensile tests at $700{ }^{\circ} \mathrm{C}$ and $800{ }^{\circ} \mathrm{C}$ show fine grains formed at the
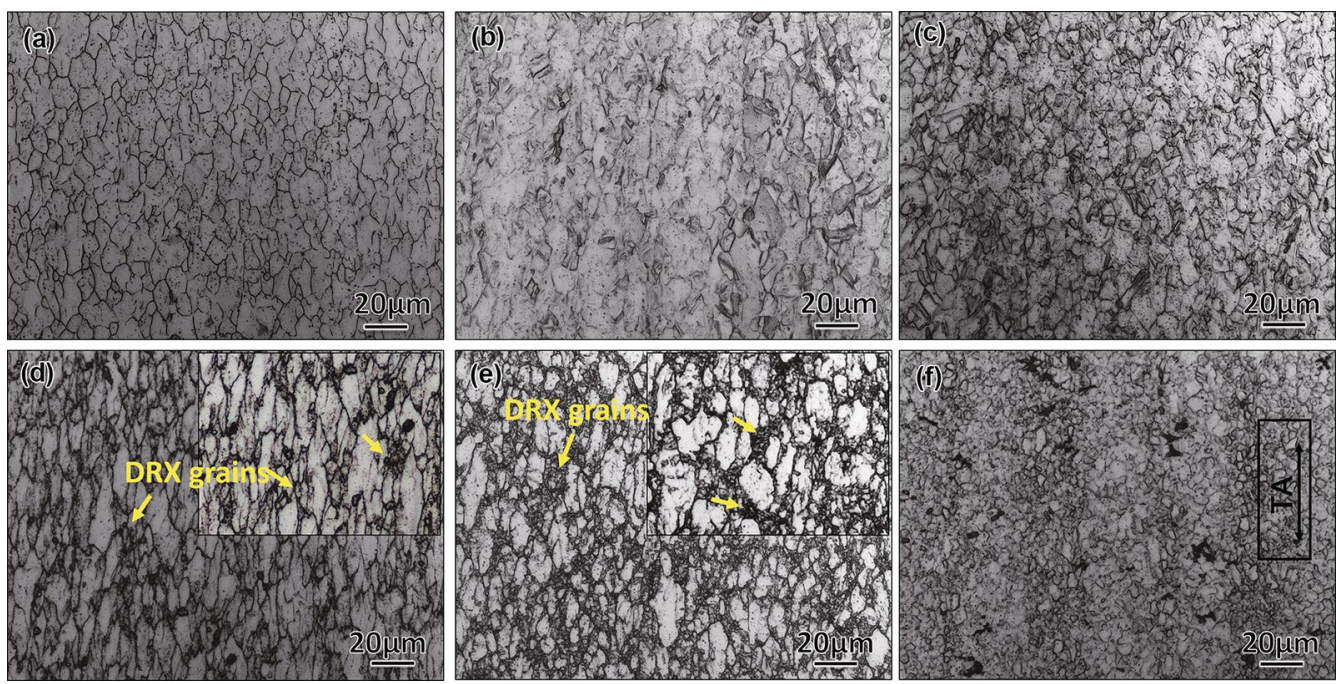

Fig. 4 Microstructure of the FG-specimens after tensile test at a RT, b $400{ }^{\circ} \mathrm{C}, \mathbf{c} 600{ }^{\circ} \mathrm{C}, \mathbf{d ~} 700{ }^{\circ} \mathrm{C}, \mathbf{e} 800{ }^{\circ} \mathrm{C}$, f $900{ }^{\circ} \mathrm{C}$; TA indicates tensile axis. The insets in $\mathbf{d}$, $\mathbf{e}$ show the microstructure at higher magnification 
original GBs, as shown in Fig. 4d, e, exhibiting incomplete dynamic recrystallization (DRX) characteristics. After the tensile test at $900{ }^{\circ} \mathrm{C}$, the FG-specimen shows a complete DRX microstructure, as shown in Fig. 4f. On the other hand, the microstructure of CG-specimens after tensile tests at RT $-800{ }^{\circ} \mathrm{C}$ contains large numbers of mechanical twins under OM observation, as shown in Fig. 5. The number of mechanical twins decreases with increasing test temperature. At a test temperature of $900{ }^{\circ} \mathrm{C}$, few mechanical twins are found under OM. It should be emphasized that a DRX microstructure is not found in CG-specimens after tensile tests.

The microstructures of the tensioned samples were further observed by TEM (as shown in Figs. 6 and 7). After tensile testing at RT, the microstructure of the FG-specimen consists of random dislocations and equiaxed dislocation cells, as shown in Fig. 6a. With increasing test temperature, the fractional area of equiaxed dislocation cells is increased at $400-600{ }^{\circ} \mathrm{C}$ compared with that at RT. In addition, the dislocation distribution is heterogeneous in the
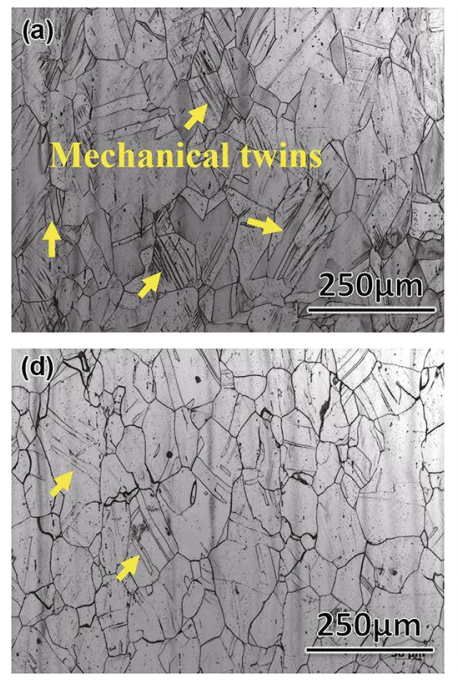
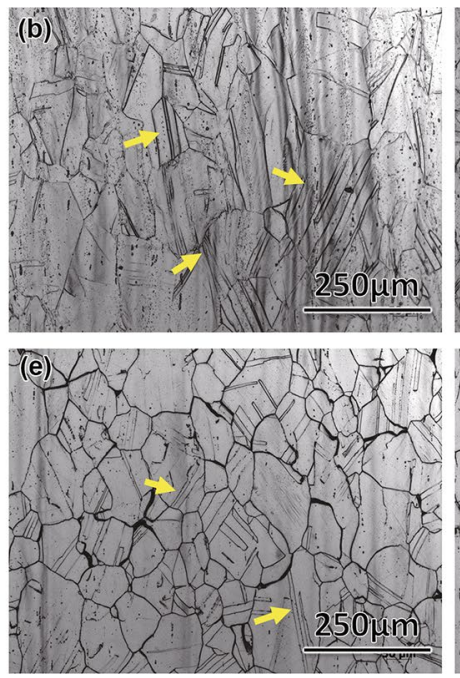
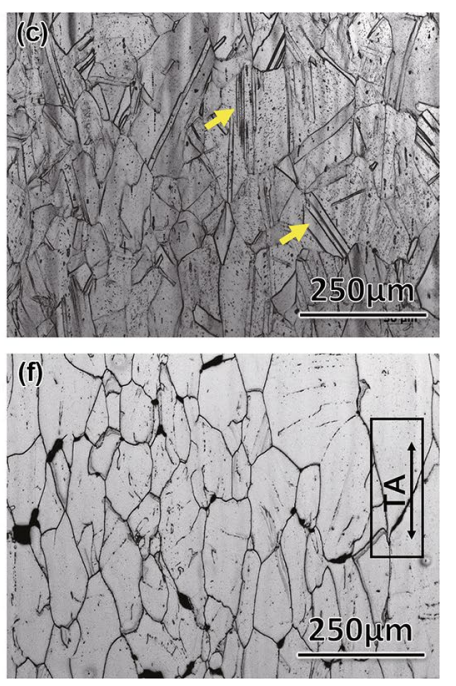

Fig. 5 Microstructure of the CG-specimens after tensile test at a RT, b $400{ }^{\circ} \mathrm{C}, \mathbf{c} 600{ }^{\circ} \mathrm{C}, \mathbf{d} 700{ }^{\circ} \mathrm{C}, \mathbf{e} 800{ }^{\circ} \mathrm{C}, \mathbf{f} 900{ }^{\circ} \mathrm{C}$; TA indicates tensile axis
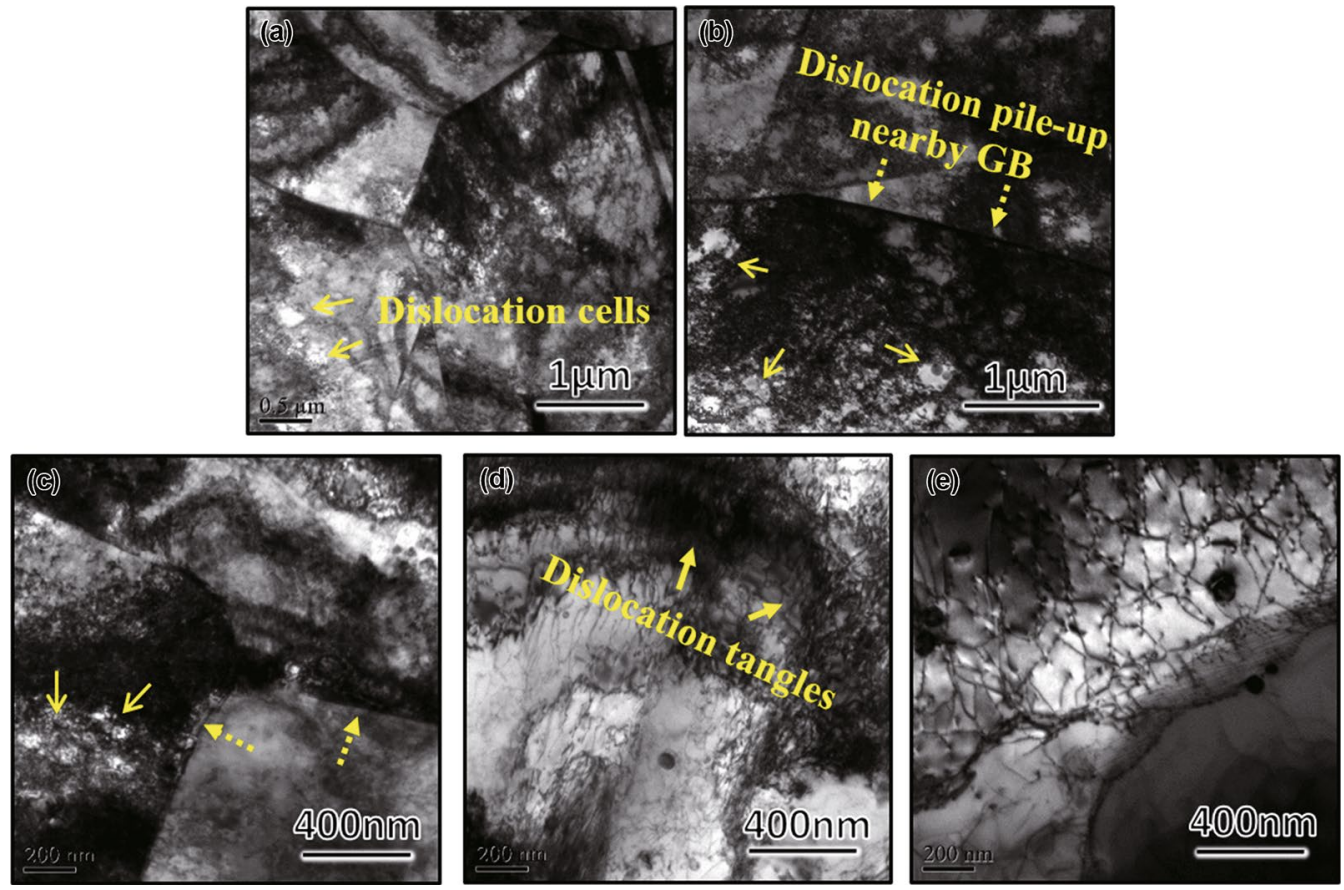

Fig. 6 TEM micrographs of FG-specimens after tensile test at a RT, b $400{ }^{\circ} \mathrm{C}, \mathbf{c} 600{ }^{\circ} \mathrm{C}, \mathbf{d} 700{ }^{\circ} \mathrm{C}, \mathbf{e} 900{ }^{\circ} \mathrm{C}$ 

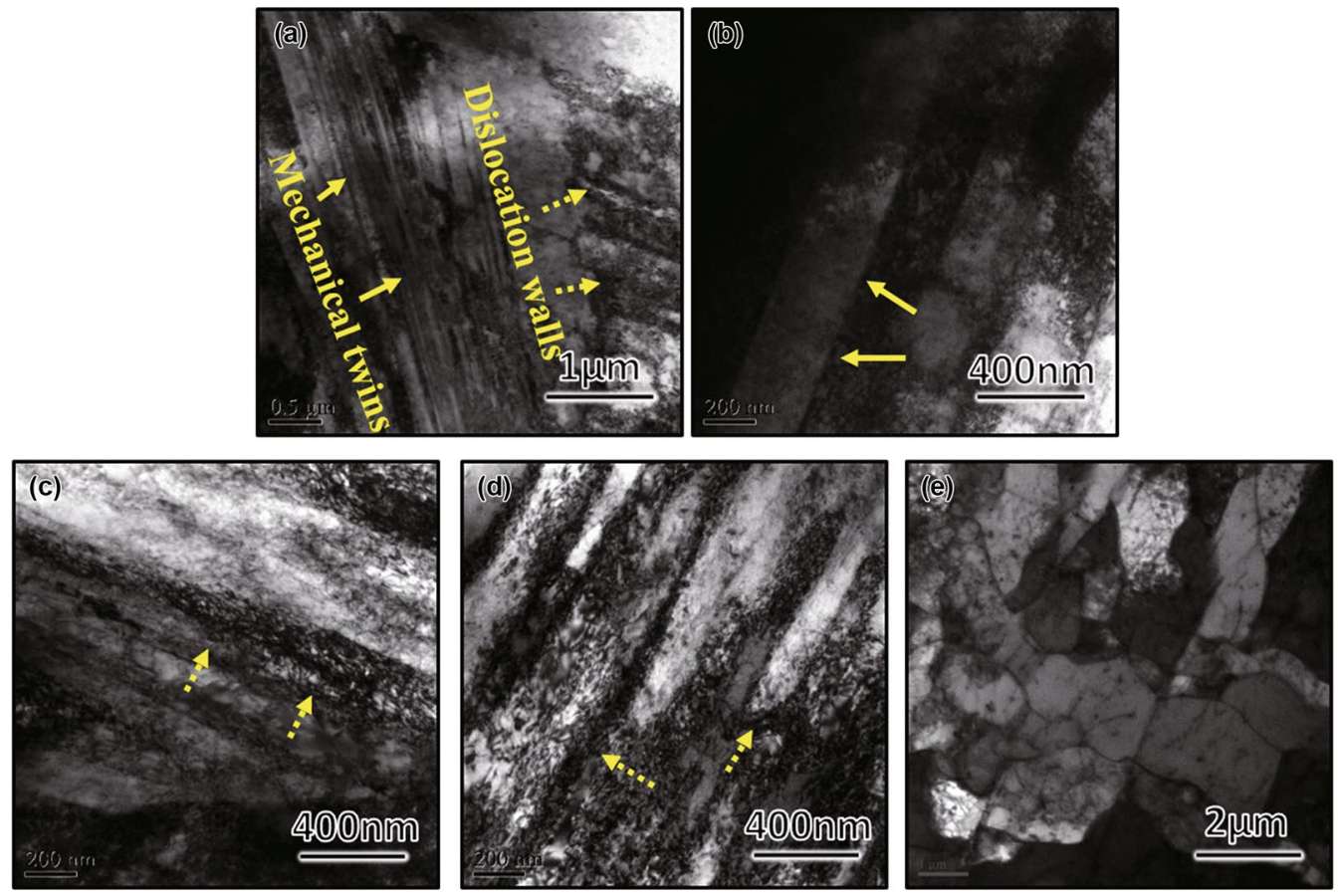

Fig. 7 TEM micrographs of CG-specimens after tensile test at a RT, b $400{ }^{\circ} \mathrm{C}, \mathbf{c} 600{ }^{\circ} \mathrm{C}, \mathbf{d} 700{ }^{\circ} \mathrm{C}, \mathbf{e} 900{ }^{\circ} \mathrm{C}$

FG-specimens, as seen in TEM micrographs. The dislocations tend to accumulate at GBs during deformation, resulting in a higher dislocation density in the vicinity of GBs, as shown in Fig. 6b, c. As the test temperature increases to $700{ }^{\circ} \mathrm{C}$, the FG-specimen shows dislocation tangles instead of dislocation cells, as shown in Fig. 6 d. At $900{ }^{\circ} \mathrm{C}$, dislocation annihilation and sub-boundary formation are found in the FG-specimen, and the dislocation density becomes even lower, as shown in Fig. 6e. On the other hand, the CGspecimen tested at RT contains large numbers of mechanical twins and elongated dislocation walls, as shown in Fig. 7a. After tensile tests at $400-600{ }^{\circ} \mathrm{C}$, the microstructure of CGspecimens contains mechanical twins, elongated dislocation walls, and a few equiaxed dislocation cells, as shown in Fig. 7b, c. The spacing between twins becomes larger with increasing test temperature. In addition, the number of mechanical twins decreases with the increase in temperature, which is consistent with the OM observation. After tension testing at $700{ }^{\circ} \mathrm{C}$, the microstructures of the CG-specimen are similar to those tested at $400-600^{\circ} \mathrm{C}$, containing elongated dislocation walls and a few equiaxed dislocation cells, as shown in Fig. $7 \mathrm{~d}$. When the test temperature increases to $900{ }^{\circ} \mathrm{C}$, sub-grains develop through the rearrangement of dislocations, as shown in Fig. 7e.

The precipitates in FG-specimens and CG-specimens after tensile tests at RT- $900{ }^{\circ} \mathrm{C}$ were investigated using SEM. There are no new-formed precipitates in any specimens after testing at RT-600 ${ }^{\circ} \mathrm{C}$ compared with the solid solution treated specimens. When the test temperature is higher than $700{ }^{\circ} \mathrm{C}$,
$M_{23} \mathrm{C}_{6}$ precipitates and sigma phases, which are not formed in the solid solution state, are found after tensile tests in FGspecimens (as shown in Figs. 8a, b, 9a, b). The fine $M_{23} \mathrm{C}_{6}$ precipitates and sigma phases mainly nucleate at GBs after the $700{ }^{\circ} \mathrm{C}$ tensile test, as shown in Fig. 8a. At a test temperature of $800{ }^{\circ} \mathrm{C}$, sigma phases are generated with DRX and distributed in the recrystallized grain interior. The size of sigma phase increases from $\sim 500 \mathrm{~nm}$ at $700{ }^{\circ} \mathrm{C}$ to $\sim 1 \mu \mathrm{m}$ at $800{ }^{\circ} \mathrm{C}$ (Fig. 8a, b). After the tensile test at $900{ }^{\circ} \mathrm{C}$, the sigma phase particles grow to $\sim 2 \mu \mathrm{m}$, while the number of particles is less than that at $800^{\circ} \mathrm{C}$, as shown in Fig. $8 \mathrm{c}$. No significant difference in $M X$ precipitates is observed in the FG-specimens after tensile tests at all temperatures.

For the CG-specimens, when the test temperature increases to $700{ }^{\circ} \mathrm{C}$ and higher, chains of $M_{23} \mathrm{C}_{6}$ particles appear along GBs (Fig. 8d-f). The size of $M_{23} \mathrm{C}_{6}$ precipitates increases when the test temperature increases from $700{ }^{\circ} \mathrm{C}$ to $900{ }^{\circ} \mathrm{C}$. Furthermore, large amounts of fine dispersive precipitates are formed in the matrix after the $800^{\circ} \mathrm{C}$ and $900{ }^{\circ} \mathrm{C}$ tests, as shown in the inset pictures in Fig. 8e, f. Scanning TEM high-angle annular dark-field (STEM-HAADF) image and STEM-EDS mapping analyses show that these precipitates are $\sim 50 \mathrm{~nm}$ in size and rich in $\mathrm{Nb}$, as shown in Fig. 9c. 

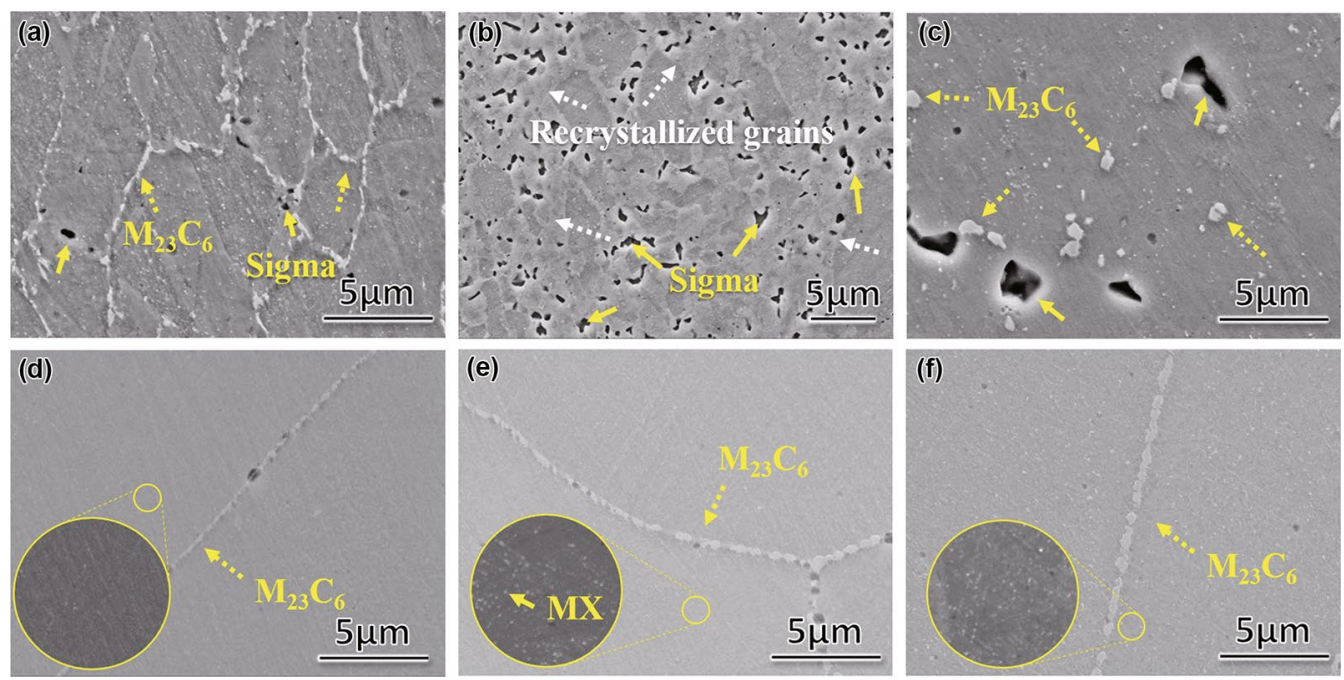

Fig. 8 SEM microstructures of FG-specimens after tensile test at a $700{ }^{\circ} \mathrm{C}, \mathbf{b} 800{ }^{\circ} \mathrm{C}, \mathbf{c} 900{ }^{\circ} \mathrm{C}$; microstructures of CG-specimens after tensile test at $\mathbf{d} 700{ }^{\circ} \mathrm{C}, \mathbf{e} 800{ }^{\circ} \mathrm{C}, \mathbf{f} 900^{\circ} \mathrm{C}$. The insets in $\mathbf{d}, \mathbf{e}, \mathbf{f}$ show the precipitates at higher magnification

\section{Discussion}

\subsection{Effects of Grain Size on Deformed Microstructure}

The deformed microstructures of austenitic steels are relevant to their deformation mechanisms, which are mainly influenced by stacking fault energy (SFE) and the microstructural constraints during deformation $[27,28]$. In this study, the main differences between the FG-specimens and the CG-specimens are grain size and the amount of precipitates. There is no clear evidence on how grain size affects SFE in austenitic stainless steels $[29,30]$. The chemical composition of the austenitic matrix at $1020^{\circ} \mathrm{C}$ and $1200^{\circ} \mathrm{C}$ is calculated by Thermo-Calc (Table 2). The difference in chemical composition of the austenitic matrix between the FG- and CG-specimens is neglectable, resulting in little difference in the SFE. Accordingly, it is reasonable to believe that the difference in deformation mechanisms of the FG- and CG-specimens may result from the different microstructural constraints induced by the dissimilar grain sizes. In polycrystals, the deformation of a grain is affected by the interaction of adjacent grains. Moreover, the width of the affected region is influenced by grain size, as reported by Miyazaki et al. [15]. In small grain size materials, a deformed grain is constrained by the surrounding grains. The effects of surrounding grains will activate more slip systems, promoting multiple slip and cross-slip during deformation [12]. As a result, equiaxed dislocation cells are formed in the FG-specimens during tensile tests even at RT. In the CG-specimens, because of the comparatively weak effects of elastic strain from surrounding grains, fewer multiple slips are activated during deformation. The deformation thus mainly occurs in grain interiors. As reported in the previous research, the slip length is larger during the inner grain deformation in coarse-grained specimens, and the twinning stress is thus smaller, making twinning nucleation more likely [27]. Additionally, as less cross-slip and multiple slips are activated, the material is deformed by planar slip of dislocations and dislocation wall structures are formed accordingly [31]. The results are also consistent with the research of Feaugas et al., in which the fraction of elongated dislocation walls in the microstructure increases with grain size, and elongated dislocation walls are not able to be generated when the grain size is lower than a critical value [12].

With increasing test temperature, the dislocation motion in the FG-specimens is further stimulated, leading to the dislocation annihilation in the $700{ }^{\circ} \mathrm{C}$ tensile test. Additionally, since the FG-specimen has a larger fractional area of GBs than the CG-specimens, and GBs act as nucleation sites for DRX, fine DRX grains start to nucleate at the original GBs in the FG-specimen during the $700{ }^{\circ} \mathrm{C}$ tensile test [32]. Therefore, with further increase in test temperature, the microstructure of the FG-specimens shows incomplete DRX at $800{ }^{\circ} \mathrm{C}$ and complete DRX characteristics at 900 ${ }^{\circ} \mathrm{C}$. During the DRX process, new-formed grains grow and replace the deformed grains, leading to a microstructure with low dislocation density. For the CG-specimen tested at 900 ${ }^{\circ} \mathrm{C}$, the dislocation re-arrangement is promoted by the crossslip and climb processes, which results in the formation of regular sub-boundaries [33].

\subsection{Evolution of Precipitates During High-temperature Tensile Test}

As shown in the results, there are three kinds of precipitates $\left(M_{23} \mathrm{C}_{6}, M X\right.$, and sigma phase) in the samples, which 

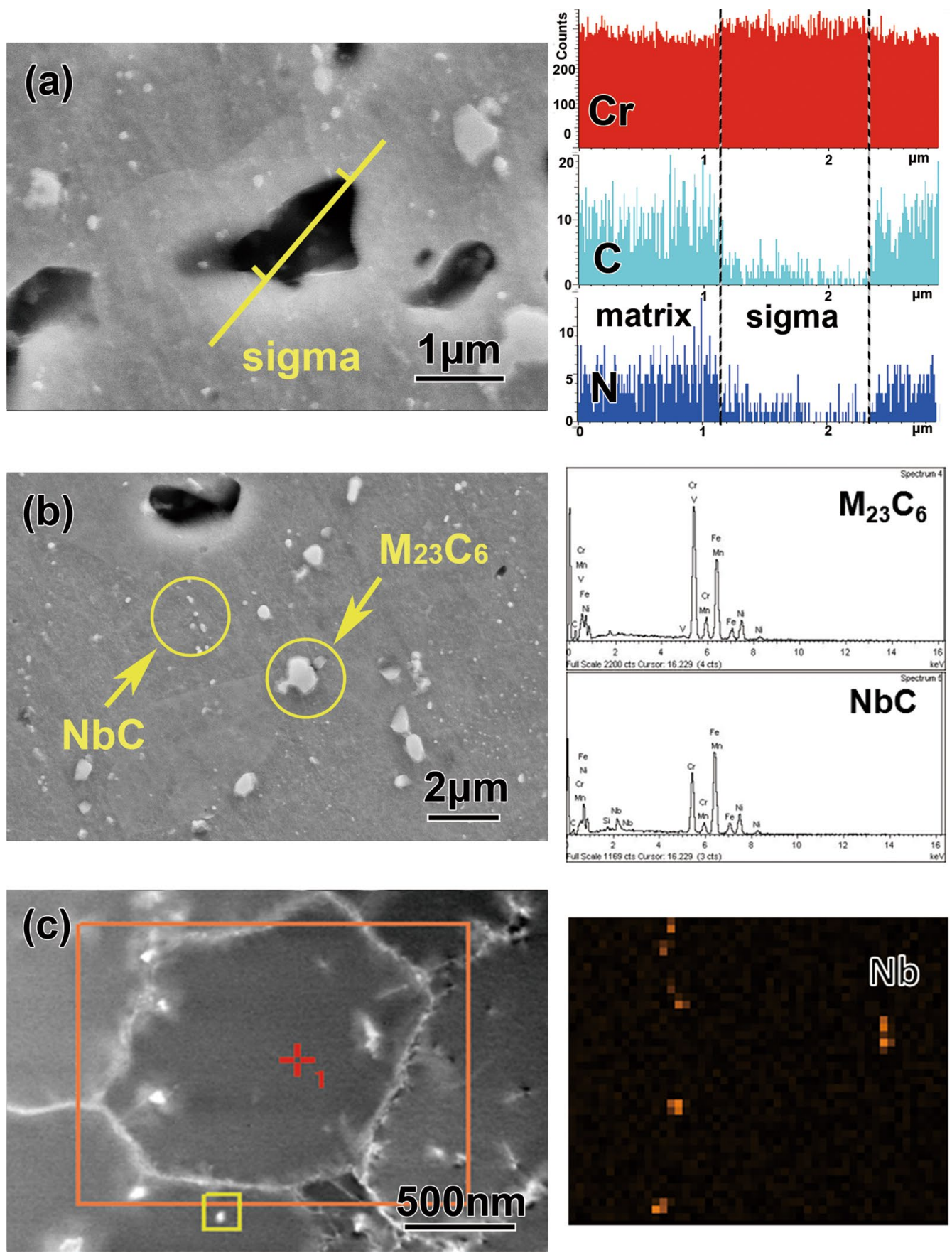

Fig. 9 a SEM-EDS concentration profile across the sigma precipitate in FG-specimen after test at $800{ }^{\circ} \mathrm{C}$, b EDS results of the precipitates in FG-specimen after test at $900{ }^{\circ} \mathrm{C}$, c STEM-HAADF image and corresponding map results of precipitates in CG-specimen after test at $900{ }^{\circ} \mathrm{C}$

Table 2 Chemical composition of austenite matrix calculated by Thermo-Calc (wt.\%)

\begin{tabular}{llllllllll}
\hline & $\mathrm{C}$ & $\mathrm{Si}$ & $\mathrm{Mn}$ & $\mathrm{Cr}$ & $\mathrm{Ni}$ & $\mathrm{Nb}$ & $\mathrm{N}$ & $\mathrm{Fe}$ & $\mathrm{Cr}_{\mathrm{eq}} / \mathrm{Ni}_{\mathrm{eq}}$ \\
\hline $\mathrm{FG}$ & 0.044 & 0.83 & 1.64 & 24.0 & 19.6 & 0.034 & 0.042 & Bal. & 1.09 \\
$\mathrm{CG}$ & 0.048 & 0.83 & 1.64 & 24.0 & 19.6 & 0.14 & 0.065 & Bal. & 1.05 \\
\hline
\end{tabular}


are generated only when the test temperature is higher than $700{ }^{\circ} \mathrm{C}$. In the $\mathrm{FG}$-specimen, $M_{23} \mathrm{C}_{6}$ carbides and sigma phases are developed at the GBs after the $700{ }^{\circ} \mathrm{C}$ tensile test. The formation of $M_{23} \mathrm{C}_{6}$ precipitates is generally to be expected in austenitic stainless steels as the test temperature is within the sensitive temperature range, within which $M_{23} \mathrm{C}_{6}$ precipitates can be formed at GBs in several minutes [34]. Sigma phase is usually considered to form after a long aging time in austenitic stainless steels, thus it is not expected that sigma phase is produced after tensile testing in the FG-specimens. Generally, precipitation of sigma phase is influenced by multiple factors such as chemical composition, grain size, and aging conditions $[35,36]$. The chemical composition will influence the stability of austenite, which can be evaluated by the $\mathrm{Cr}_{\mathrm{eq}} / \mathrm{Ni}_{\mathrm{eq}}$ ratio $\left(\right.$ where $\mathrm{Cr}_{\text {eq }}=\mathrm{Cr}+1.5 \mathrm{Si}+0.5 \mathrm{Nb} ; \mathrm{Ni}_{\text {eq }}=\mathrm{Ni}+39$ $\mathrm{C}+26 \mathrm{~N}+0.5 \mathrm{Mn}$ ) [37]. According to the thermodynamic calculation listed in Table 2, there is almost no difference in $\mathrm{Cr}_{\mathrm{eq}} / \mathrm{Ni}_{\mathrm{eq}}$ ratio between the two specimens. Thus, it is reasonable to believe that the sigma precipitation does not result from the matrix compositions. Additionally, because of the limited soaking time at high temperature during the tensile test, the grain size makes little difference on the sigma phase precipitation. During DRX, the element diffusion can be promoted by the moving GBs. The moving boundaries sweep the deformed grains and incorporate the defects and dislocations, which increases the GB free volume. The diffusivity increases accordingly, since effective diffusion can occur only when the free volume is large enough [38]. Recrystallizing accelerates the diffusion rate for mass transport of the solute atoms, thus further promoting sigma precipitation. This is also consistent with the research by Singhal and Hsieh, which shows that sigma phases are formed in a shorter time when the DRX occurs $[39,40]$.

The precipitation of $M_{23} \mathrm{C}_{6}$ is also found in CG-specimens after testing at $600-900{ }^{\circ} \mathrm{C}$. This phenomenon has been widely investigated [41, 42] and is not discussed here. Except for the GB $M_{23} \mathrm{C}_{6}$, fine dispersive $M X$ precipitates are formed dispersively in the CG-specimens after testing at $800{ }^{\circ} \mathrm{C}$ and $900{ }^{\circ} \mathrm{C}$. This is because the solution temperature of the CG-specimens is about $1200{ }^{\circ} \mathrm{C}$, at which most precipitates are dissolved in the matrix. The austenitic matrix is supersaturated with interstitial carbon and nitrogen atoms after solution treatment. Therefore, the carbonitrides can be formed in a short time during testing at $800{ }^{\circ} \mathrm{C}$ and $900{ }^{\circ} \mathrm{C}$. On the other hand, since a large amount of $M X$ precipitates are formed in the FG-specimens after hot rolling and solution heat treatment at $1020^{\circ} \mathrm{C}$, the concentration of interstitial atoms in austenitic matrix of the FG-specimens is expected to be quite low. As a result, there are few newformed $M X$ precipitates during tensile tests at $800{ }^{\circ} \mathrm{C}$ and $900{ }^{\circ} \mathrm{C}$ compared with the solution state.

\subsection{Correlation Between Microstructure Evolution and Tensile Properties}

The FG-specimens having higher YS than the CG-specimens at RT- $-800{ }^{\circ} \mathrm{C}$ is attributed to the accumulation of dislocations at the GBs according to the Hall-Petch law, and the strengthening effect of larger amounts of $M X$ precipitates in the FG-specimens. However, at $600-800{ }^{\circ} \mathrm{C}$, the UTS of the FG-specimens decreases rapidly, becoming lower than that of the CG-specimens. For the FG-specimens, more slip systems are activated during deformation, and the multislip and cross-slip are thus accelerated, leading to severe dislocation annihilation in the FG-specimens. When the test temperature increases beyond $600{ }^{\circ} \mathrm{C}$, the annihilation and interaction of dislocations are further promoted. The accelerated cross-slipping and larger GB fraction promote the onset of recovery and DRX. During tensile deformation, the deformed microstructure has a high density of dislocations and other crystalline defects to store the system energy. DRX usually begins to form grain embryos at sites with higher energy. Grain embryos will then absorb the dislocations and grow into deformed grains. As a consequence, recrystallization grains with a very low density of dislocations and even free dislocations are produced, thus softening the material [43]. Correspondingly, the UTS of the FGspecimens decreases rapidly. For CG-specimens tensioned at 600-800 ${ }^{\circ} \mathrm{C}$, although some recovery occurs, the deformed microstructure still consists of mechanical twins, elongated dislocation walls, and equiaxed dislocation cells. The twinning thickness becomes wider and more dislocation cells are found. Accordingly, the UTS of the CG-specimens decreases comparatively slowly at $600-800{ }^{\circ} \mathrm{C}$. On the other hand, the YS is not much influenced by the recovery and DRX. This is because the recovery and DRX barely occur before the initiation of plastic deformation at RT-800 ${ }^{\circ} \mathrm{C}$. Therefore, the YS of the FG-specimens is still higher than that of the CG-specimens.

When the test temperature is higher than $800{ }^{\circ} \mathrm{C}$, both the YS and UTS of FG-specimens decrease markedly. The decrease in UTS of the FG-specimens is due to the DRX softening effect, as discussed above. The decrease in YS in the FG-specimens is caused by faster dislocation annihilation at higher temperature. This is because the density of dislocations in the FG-specimens is much higher than that of the CG-specimens, which accelerates dislocation annihilation in the FG-specimens at high temperature. On the other hand, the YS of the CG-specimens only changes slightly at $800{ }^{\circ} \mathrm{C}$ and $900{ }^{\circ} \mathrm{C}$ compared with lower temperatures, although the UTS decreases rapidly. This is attributed to the precipitation strengthening induced by the formation of dispersive $M X$ precipitates in the CG-specimens during tensile tests. This phenomenon is similar to the YS anomaly in some superalloys at $800-900{ }^{\circ} \mathrm{C}$ [44]. The decrease in UTS is mainly 


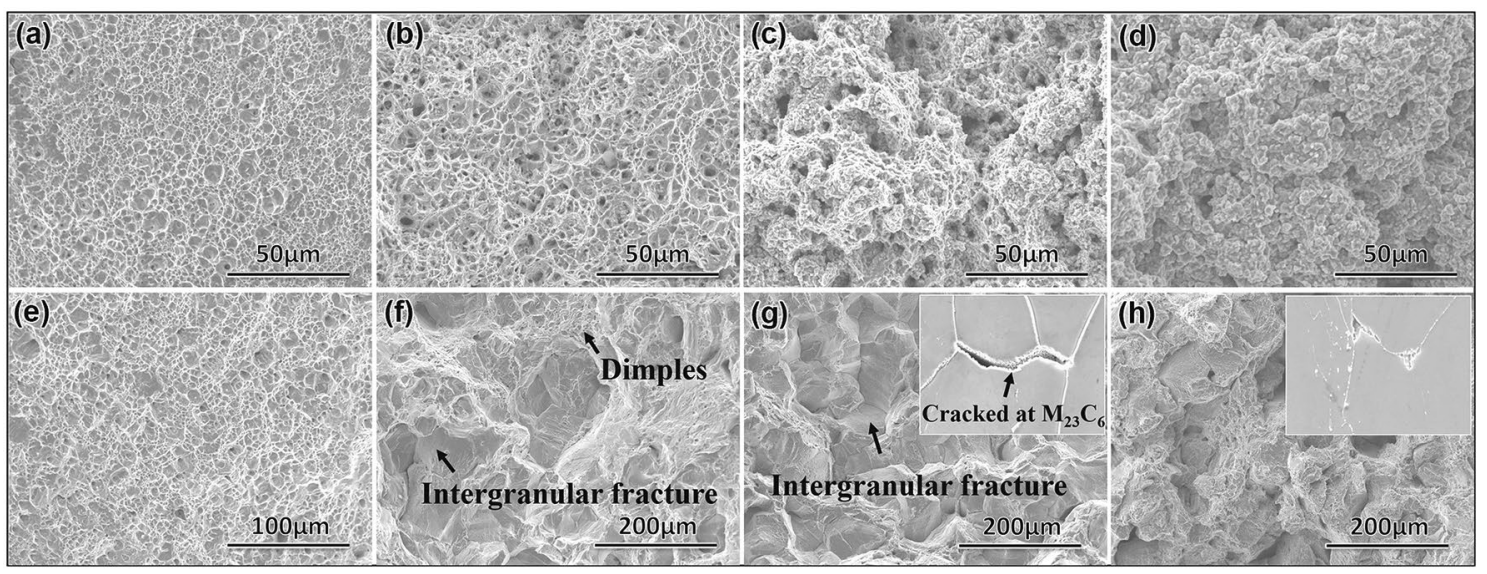

Fig. 10 Fracture morphology of FG-specimens after tensile test at a $600{ }^{\circ} \mathrm{C}, \mathbf{b} 700{ }^{\circ} \mathrm{C}, \mathbf{c} 800{ }^{\circ} \mathrm{C}, \mathbf{d} 900{ }^{\circ} \mathrm{C}$; CG-specimens after tensile test at e $600{ }^{\circ} \mathrm{C}, \mathbf{f} 700{ }^{\circ} \mathrm{C}, \mathbf{g} 800{ }^{\circ} \mathrm{C}, \mathbf{h} 900{ }^{\circ} \mathrm{C}$. The insets in $\mathbf{g}, \mathbf{h}$ show the corresponding figures of cracks in longitudinal section

ascribed to the accelerated recovery process at higher temperature. Dislocations are rearranged, and sub-boundaries are formed as the results of the interaction of dislocations, and the dislocation density decreases correspondingly.

In addition to the strength, the ductility variations between the FG-specimens and the CG-specimens are also different at high temperatures. The ductility of FG-specimens increases considerably with the temperature increasing from $600{ }^{\circ} \mathrm{C}$ to $800{ }^{\circ} \mathrm{C}$, and slightly decreases at $900{ }^{\circ} \mathrm{C}$. The increase in elongation in the FG-specimens is caused by the recovery and DRX, which soften the material and enhance its ductility. At $900{ }^{\circ} \mathrm{C}$, the precipitation of large size sigma phases causes the decrease in elongation of the FG-specimen and lessens the $Z$ reduction. On the other hand, the ductility of CG-specimens first decreases at $600-800{ }^{\circ} \mathrm{C}$ and then increases at $800-900{ }^{\circ} \mathrm{C}$. The fracture morphology of the CG-specimens was observed using SEM (Fig. 10). Intergranular fracture is found in the CG-specimens after tension testing at $700{ }^{\circ} \mathrm{C}, 800{ }^{\circ} \mathrm{C}$, and $900{ }^{\circ} \mathrm{C}$. The microstructure of the failed specimens in longitudinal section further shows that the intergranular cracking occurs along with GB $M_{23} \mathrm{C}_{6}$ precipitates (the inset in Fig. $10 \mathrm{~g}$ ). These $M_{23} \mathrm{C}_{6}$ carbides at the GBs provide a preferential site for cavity nucleation owing to the stress concentration during deformation [45]. This leads to a decrease in elongation during tensile tests at $600-800{ }^{\circ} \mathrm{C}$. When the temperature is increased to 900 ${ }^{\circ} \mathrm{C}$, the recovery process and formation of sub-boundaries largely decrease the dislocation density, inducing a softening effect. Therefore, the propagation of the cracks that form at the interface between $M_{23} \mathrm{C}_{6}$ and austenitic matrix can be suppressed. This is supported by the cross-sectional observation, in which the cracks only exist at partial segments of GBs in the sample tested at $900{ }^{\circ} \mathrm{C}$ (the inset in Fig. 10h). Consequently, the elongation of the CG-specimen at $900{ }^{\circ} \mathrm{C}$ is greater compared with that at $800{ }^{\circ} \mathrm{C}$. It should be noted that GB $M_{23} \mathrm{C}_{6}$ precipitates were also found in the FG-specimens at $700{ }^{\circ} \mathrm{C}$ and $800{ }^{\circ} \mathrm{C}$, whereas intergranular fracture was not observed (as shown in Fig. 10). This is because the occurrence of DRX decreases the dislocation density and releases the stress concentration, and thus prevents crack formation.

\section{Conclusions}

1 The tensile strength decreases more quickly in finegrained specimens than in coarse-grained specimens when the test temperature increases from $600{ }^{\circ} \mathrm{C}$ to 800 ${ }^{\circ} \mathrm{C}$. This is because more slip systems are activated during deformation in fine-grained microstructure, resulting in the accelerated dynamic recovery and recrystallization.

2 Sigma phases are formed in fine-grained specimens when the test temperature is higher than $700{ }^{\circ} \mathrm{C}$, while they do not appear in coarse-grained specimens. The precipitation of sigma phases is promoted by the simultaneous recrystallization during the tensile tests.

3 The ductility minimum is found in coarse-grained specimens in the $800{ }^{\circ} \mathrm{C}$ tensile test. The minimum ductility in coarse-grained specimens arises from the $M_{23} \mathrm{C}_{6}$ precipitation at grain boundaries, which promote intergranular cracking, thus decreasing the ductility.

Acknowledgements This work was financially supported by the Youth Innovation Promotion Association, Chinese Academy of Sciences (No. 2013126), the LiaoNing Revitalization Talents Program under (No. XLYC1807022), the Guangdong Innovative and Entrepreneurial Research Team Program (No. 2016ZT06G025), and the Guangdong Basic and Applied Basic Research Foundation (No. 2019A1515110886). We thank Editage Company for English language 
editing. We also thank Dr. Sanjooram Paddea and Dr. Rengen Ding in CEAM for the suggestions on the writing.

\section{References}

[1] Z. Zhang, Z. Hu, H. Tu, S. Schmauder, G. Wu, Mater. Sci. Eng. A 681, 74 (2017)

[2] Y. Xiong, T. He, J. Wang, Y. Lu, L. Chen, F. Ren, Y. Liu, A.A. Volinsky, Mater. Des. 88, 398 (2015)

[3] Y. Takahashi, T. Yamane, J. Mater. Sci. 14, 2818 (1979)

[4] R.C.D. Sousa, J.C. Cardoso, A.A. Tanaka, A.C.S. Oliveira, W.E. Ferreira, J. Mater. Sci. 41, 2381 (2006)

[5] C.R. Hutchinson, H.S. Zurob, C.W. Sinclair, Y.J.M. Brechet, Scr. Mater. 59, 635 (2008)

[6] D. West, J. Hulance, R.L. Higginson, G.D. Wilcox, Mater. Sci. Technol. 29, 835 (2013)

[7] A.D. Schino, M. Barteri, J.M. Kenny, J. Mater. Sci. 38, 4725 (2003)

[8] B.P. Kashyap, Acta Mater. 50, 2413 (2002)

[9] E. Ulvan, A. Koursaris, Metall. Trans. A 19, 2287 (1988)

[10] S.L. Mannan, K.G. Samuel, P. Rodriguez, Mater. Sci. Eng. A 68, 143 (1985)

[11] V.K. Rao, D.M.R. Taplin, P.R. Rao, Metall. Trans. A 6, 77 (1975)

[12] X. Feaugas, H. Haddou, Philos. Mag. 87, 989 (2007)

[13] M. Janeček, K. Tangri, J. Mater. Sci. 30, 3820 (1995)

[14] Z. Jiang, J. Lian, B. Baudelet, Acta Metall. Mater. 43, 3349 (1995)

[15] S. Miyazaki, K. Shibata, H. Fujita, Acta Metall. 27, 855 (1979)

[16] X. Feaugas, H. Haddou, Metall. Mater. Trans. A 34, 2329 (2003)

[17] H.T. Liu, Y. Shen, J.W. Ma, P.F. Zheng, L. Zhang, J. Mater. Eng. Perform. 25, 3599 (2016)

[18] P.K. Venkiteswaran, M.W.A. Bright, D.M.R. Taplin, Mater. Sci. Eng. A 11, 255 (1973)

[19] G.D. Hu, P. Wang, D.Z. Li, Y.Y. Li, Mater. Sci. Eng. A 711, 543 (2018)

[20] S.H. Park, J.K. Kim, J.H. Kim, A Statistical Study on StressStrain Relation of AISI 304 Stainless Steel Under Elevated Temperatures, in Materials with Complex Behaviour: modelling, Simulation, Testing, and Applications, ed. by A. Öchsner, L.F.M. Silva, H. Altenbach (Springer, Berlin, 2010), pp. 3-18
[21] R.A. Varin, Mater. Sci. Eng. A 94, 93 (1987)

[22] B. Peng, H. Zhang, J. Hong, J. Gao, H. Zhang, Q. Wang, J. Li, Mater. Sci. Eng. A 528, 3625 (2011)

[23] L.G. Zheng, X.Q. Hu, X.H. Kang, D.Z. Li, Mater. Des. 78, 42 (2015)

[24] B. Peng, H. Zhang, J. Hong, J. Gao, Q. Wang, H. Zhang, Mater. Sci. Eng. A 527, 1957 (2010)

[25] K.K. Singh, S. Sangal, G.S. Murty, Mater. Sci. Technol. 18, 1168 (2002)

[26] J.M. Robinson, M.P. Shaw, Int. Mater. Rev. 39, 113 (1994)

[27] G. Dini, A. Najafizadeh, R. Ueji, S.M. Monir-Vaghefi, Mater. Des. 31, 3395 (2010)

[28] C. Shin, S. Lim, H.H. Jin, P. Hosemann, J. Kwon, Mater. Sci. Eng. A 622, 67 (2015)

[29] A. Das, Metall. Mater. Trans. A 47, 748 (2016)

[30] J. Lu, L. Hultman, E. Holmström, K.H. Antonsson, M. Grehk, W. Li, L. Vitos, A. Golpayegani, Acta Mater. 111, 39 (2016)

[31] I. Gutierrez-Urrutia, D. Raabe, Acta Mater. 59, 6449 (2011)

[32] M.E. Wahabi, L. Gavard, F. Montheillet, J.M. Cabrera, J.M. Prado, Acta Mater. 53, 4605 (2005)

[33] D.J. Michel, J. Moteff, A.J. Lovell, Acta Metall. 21, 1269 (1973)

[34] R.A. Carolan, R.G. Faulkner, Acta Metall. 36, 257 (1988)

[35] T. Sourmail, Mater. Sci. Technol. 17, 1 (2001)

[36] A. Perron, C.T. Masclet, X. Ledoux, F. Buy, T. Guilbert, S. Urvoy, S. Bosonnet, F. Cortial, G. Texier, C. Harder, V. Vignal, P. Petit, J. Farré, E. Suzon, Acta Mater. 79, 16 (2014)

[37] J. Barcik, Mater. Sci. Technol. 4, 5 (1988)

[38] Y. Amouyal, E. Rabkin, Acta Mater. 55, 6681 (2007)

[39] L.K. Singhal, S.N. Bhargava, J.W. Martin, Metall. 5, 31 (1972)

[40] C.C. Hsieh, D.Y. Lin, W. Wu, Mater. Sci. Eng. A 467, 181 (2007)

[41] K. Kaneko, T. Fukunaga, K. Yamada, N. Nakada, M. Kikuchi, Z. Saghi, J.S. Barnard, P.A. Midgley, Scr. Mater. 65, 509 (2011)

[42] R. Hu, G. Bai, J. Li, J. Zhang, T. Zhang, H. Fu, Mater. Sci. Eng. A 548, $83(2012)$

[43] S. Wang, L. Wang, Y. Liu, G. Xu, B. Zhang, G. Zhao, Acta Metall Sin.-Engl. Lett. 24, 295 (2011)

[44] A.K. Roy, V. Marthandam, Mater. Sci. Eng. A 517, 276 (2009)

[45] H.U. Hong, S.W. Nam, Mater. Sci. Eng. A 332, 255 (2002) 